\title{
'They're so into it': Perceptions of 'Religion', Orthodoxy and Belonging in Post-Yugoslav Serbia
}

\author{
Nicholas Lackenby \\ University College London
}

\begin{abstract}
Much has been written about how people embraced new religious identities following the collapse of socialist regimes. This article argues that it is also important to consider the perspective of those (sometimes sceptical) people who may be less eager to participate in new, emergent forms of embodied religious practice. In the ethnographic context of post-Yugoslav Serbia, I ask how 'religion' is perceived, constituted, and evaluated from the sidelines. How do local perceptions of what 'religion' is connect - and collide - with wider ethnomoral communities? I make this argument through a close analysis of an interview with a female interlocutor, a woman who - whilst declaring herself to be unambiguously 'Serbian' and 'Orthodox' - is uncertain about the religious transformations that she sees happening around her. Anthropologists must attend to the positionality of people who may feel at once related to and detached from societal transformations, and how they make sense of such changes in their own terms.
\end{abstract}

\section{Keywords}

Orthodox Christianity, postsocialism, religious change, Serbia

\section{Contact Address}

Department of Anthropology, University College London, 14 Taviton Street, London, WC1H 0BW, UK. E-mail: n.lackenby@ucl.ac.uk

As European socialist regimes collapsed at the end of the 1980s and the beginning of the 1990s, new forms of religious practice - previously restricted by atheistic, secular policies - were free to re-emerge into the public sphere. Social scientists have considered extensively the ways in which post socialist subjects sought meaning in the new interpretative devices offered by national churches and foreign missionaries. Having grown up in secular state systems where open expression of spirituality was - at best - viewed with suspicion, the possibility to openly cultivate oneself as a religious actor was in many ways a novel experience. Drawing on the thinking of Talal Asad, Mathijs Pelkmans argued that, after 
socialism, anthropologists must consider "the process by which people came to have a 'religious identity' and by which religion became objectified" (2009: 6; original emphasis). In this article, I follow in a similar vein to Pelkmans.

However, rather than considering how people find solace and meaning in new religious identities during socio-economic upheaval, I argue that we have to explore the perspectives of those who were not motivated to do so. What about people who feel unable to participate fully in newfound spiritual euphoria? How do they judge it? Times of 'transition' are not solely defined by people appropriating new spiritualities, but are also moments where (sometimes sceptical) people are forced to contemplate their own and others' religiosity. This can involve local processes of categorization, whereby people work out what constitutes 'sincere' morally-upstanding practice, and what might be deemed performative and superficial pretence.

In his critique of 'universalist' definitions of religion, Asad argued that the way in which 'religion' is defined at a particular moment is necessarily "the historical product of discursive processes" (1993: 29). Crucially, 'religion' - far from being a "transhistorical essence" (ibid.) - is always defined and delimited by social actors at a particular moment. Here my interest is in how 'religious' practice comes to be defined by those who look on from the sidelines. How do local perceptions of what 'religion' is connect - and collide - with wider ethno-moral communities, communities which may be seen as actually subsuming such emergent 'religious' elements?

To address this issue, I focus on the case of post-Yugoslav Serbia. Under Yugoslav socialism, religious expression was restricted and stigmatised, and Serbian Orthodoxy in particular was associated with aggressive Serbian nationalism - a potential thorn in the side of Marshal Tito's post-war, multi-national, multi-religious state. However, in the 1980s, as the socialist state weakened, the hitherto marginalised Serbian Orthodox Church began to reassert itself as the protector of the Serbian people and became increasingly present in the public sphere (Perica 2002; Radić 2000). Orthodox spirituality and liturgical practice became, for some, a way of navigating a tumultuous moment.

In contemporary Serbia, as in other traditionally Orthodox countries, ethnic and confessional identities are deeply entwined; being 'Serbian' is practically synonymous with being 'Orthodox'. Pew research on 'religious commitment' from 2018 found that $34 \%$ of Serbs "say that religion is very important in their lives". ${ }^{1}$ That said, as has frequently been shown, only a slim minority attend church regularly; in 2017 Pew placed a mere 6\% of Serbs as claiming to attend church on a weekly basis. ${ }^{2}$

From late 2016 to early 2018, I conducted ethnographic fieldwork in and around the central Serbian town of Kraljevo. During my research, which focused on the state of contemporary Orthodox practice, I encountered numerous people who willingly volunteered

\footnotetext{
${ }^{1}$ See: https://www.pewresearch.org/fact-tank/2018/12/05/how-do-european-countries-differ-in-religiouscommitment/ (accessed 24 December 2020).

2 See: https://www.pewforum.org/2017/05/10/religious-belief-and-national-belonging-in-central-andeastern-europe/pf-05-10-2017_ce-europe-00-18/ (accessed 20 December 2020).
} 
their own commentaries on the religious situation in their country. As a foreigner, my very presence invited people to comment on Serbia as a whole, to interpret it for me, and to offer lay sociological accounts of what they thought was going on. People frequently clarified their own religiosity - "I'm not a big believer", "I don't need the Church to know God" or their personal relationship to the institutional Serbian Orthodox Church. Sometimes, they offered concrete advice on how they thought I should conduct my research (ranging from suggesting 'good priests' with whom to speak, or proposing that I categorically avoid priests all together). In this article, I focus on an interview with one person who was eager to share her perceptions of Serbia's religious transformations, a woman in her early thirties whom I call Milica.

Over time, I got to know Milica, her husband, and her parents very well. Milica grew up in a village near Kraljevo before going to the University of Belgrade to study Serbian language and literature. Today, she teaches Serbian language at a local primary school. As will become clear, Milica is good at expressing her thoughts on religious matters, with the lucidity of someone who has received a university education. She is very certain about her confessional identity: "I'm baptised, that means I'm Orthodox." She also describes herself as an 'agnostic' and, at the time of our interview in Spring 2017, had only ever attended the Orthodox Divine Liturgy once. My purpose is not to pick apart what some may see as contradictions in Milica's position, but rather to explore how she situates her own integrated and meaningful sense of ethnic and confessional belonging against apparently new forms of 'religious' practice emerging from the same Orthodox tradition.

Nor do I present Milica as 'representative' of a particular segment of the population. Rather, like Jarett Zigon's fascinating 'moral portrait' of a Russian Orthodox believer, my discussion of Milica reveals her views which "may not be entirely unique but also may not be entirely shared" (2008: 88). For example, her fascination with (and palpable concern for) Serbian cultural heritage stems in no small part from her own upbringing. Her parents are resolutely proud of their Serbian identity, and many of my conversations at their house dwelt on national themes, concerns, and conspiracies. Being a former student of Serbian language and literature surely also influences Milica's concern for cherishing her national heritage. (She was particularly insistent about writing with the Serbian Cyrillic script, not the Latin.) ${ }^{3}$ That being said, Milica's (sometimes critical) views of liturgical Orthodoxy were ones that I heard widely across Serbia, especially from more educated people. The uncertainty and bemusement that she reveals are definitely not unique to her alone. In what follows, I analyse my interview with her, respecting, for the most part, the order in which she raised her concerns.

\footnotetext{
${ }^{3}$ According to the 2006 constitution, the official script of Serbia is Cyrillic, although the Latin script is very widely used and understood in everyday life and on social media.
} 


\section{Serbs don't know the Bible}

The first time I met Milica she told me that, insofar as 'religion' was concerned, amongst Serbs there was 'no enlightenment' (nema prosvećenosti). A few weeks later, we sat in her comfortable living room to conduct a more detailed interview. On this occasion, she admitted that speaking about a lack of 'enlightenment' might have sounded rather drastic. She rephrased her idea, claiming instead that there was 'insufficient awareness' (nedovoljno obavestenosti) in Serbia about religious matters.

I think that there's not enough education (obrazovanje) about it amongst the people ( $u$ narodu). I'm not speaking institutionally, but amongst the people, in the people as a whole, simply that they're not interested enough to devote themselves to that question. They will say that they're Orthodox. But they don't engage with that theme in the right way. They don't study religion ... When I say study, I don't mean going into depth in an academic sense. But at least to know the framework they're in.

Milica effectively passes judgement on those who claim to be 'Orthodox' but who, she feels, do not know enough about the faith they practise. She is irritated by (what she perceives as) a discrepancy between the outward form and the content of religious practice. Her irritation about such a discrepancy recurs throughout the interview.

Milica then outlined more specifically the sort of knowledge that she feels is lacking amongst her compatriots.

Serbs don't know the Bible enough. ... So if you questioned the people that you meet at a service they wouldn't know the content of the Bible. And they perceive it as a sort of literature (stivo) that those who are Orthodox have to keep to, not understanding what's in it. So the Bible is something which is taken for granted. And they've accepted everything [i.e. unreflectingly], but if you ask a question - "what's inside?" - that will be problematic [for them to answer].

Milica's broad assessment is that 'Serbs' (her critique is of the national community as a whole) are not well enough acquainted with biblical content. Note that Milica does not claim to be an expert herself, though her literary studies (and comments she makes later in the interview) indicate that she is probably more knowledgeable than most. But her point is that people who attend church are not well read in the core text, and that this is a cause for concern. She suggests that her point could be proven if I were to question such churchgoers directly.

Milica is especially troubled by people who take the Bible unreflectingly as a symbol. Curiously, her emphasis on the centrality of reading and knowing the Bible is in fact more reminiscent of the anthropological literature on Protestantism than that on Orthodox 
Christianity (cf. Bielo 2009a; 2009b; Malley 2004). ${ }^{4}$ For Milica, the Bible is effectively emblematic of what Orthodox Christianity is about, and knowledge of it thus becomes a gauge by which she measures others' religiosity. However, her view of a widespread lack of biblical knowledge - whilst not necessarily inaccurate - might actually miss what makes churchgoing compelling. My more practising interlocutors - regular churchgoers - would be quite uncomfortable with her interpretation. It is not for the laity to read and interpret the Bible, they claim, but this is rather the role of bishops, priests and theologians. Milica (who, as we will see, is herself uncertain about her own religious convictions) emphasizes understanding. Nevertheless, such an attention to biblical text may not actually be the priority of regular churchgoers who strive to live a 'liturgical life' (see Lackenby 2020; Pop 2018) and who often emphasise the importance of 'feeling' over 'rationality'. That is certainly not to suggest that practising Orthodox revel in their ignorance, but rather that they derive meaning through fasting, attending liturgies, and listening to homilies, not through the attentive study of scripture.

\section{Transition, crisis and faith as 'fashion'}

At this point in the conversation, we turned to Milica's more general observations about religious activity in contemporary Serbia.

As time passes there's more of it [churchgoing]. Generally speaking, people are engaging with it. There is that big fast, you know, before Easter. ... And there is that one before Christmas. And let's say over the last ten years - it's more pronounced as time goes by - people take Communion. And they fast those forty days, as much as is necessary. And before it wasn't like that - when we were children, let's say twenty years ago. ... In my surroundings, it wasn't there. And now I see that it is there in my surroundings.

If the quantitative studies are to be believed, then Milica is very much part of the majority in her perception of religious change. In 2017, Pew found that, in Serbia, 69\% of those questioned felt that "their country is very/somewhat religious today". This is in contrast to the $46 \%$ who felt that "their country was very/somewhat religious in the 1970 s \& 1980s". Not only is her viewpoint widely shared, it would seem to be substantively confirmed by sociological studies. Surveys comparing data from the 1980s and 1990s invariably show an exponential rise in Serbs participating in religious activities (see Blagojević 2008: 4243; Radić 2011: 25). As a broad indicator, Pew found that in 2017 a majority of $64 \%$ of

\footnotetext{
${ }^{4}$ The way in which Protestant thought inflects Milica's thinking about interiority, sincerity and scripture - and so informs her critique of Orthodoxy - is a much wider issue that it is not possible to address here in depth. ${ }^{5}$ See: https://www.pewforum.org/2017/05/10/religious-belief-and-national-belonging-in-central-andeastern-europe/pf_17-05-10_centraleasterneurope_sovietrepreligion420px/ (accessed 19 December 2020).
} 
Orthodox Christians in Serbia "fast during holy times such as Lent" ${ }^{6}$ That there is more pronounced religious activity in the public sphere since Milica's childhood in the late 1980 s and early 1990s is thus basically fair observation. She muses on the reason for this:

It means that the need to believe, and maybe demonstrate it, is more pronounced. Or people have a need to be in the faith more. Now, whether that's on a conscious or unconscious level, I don't know. Overall, there is the presence of faith at every step.

Milica speaks about the need people now feel to be 'in the faith' ( $u$ veri). This expression is quite widespread in Serbia, and it refers implicitly to the Serbian Orthodox faith. Those who attend church regularly will often refer to themselves as being 'in the faith', distinguishing themselves from the majority of the population who are nominally Orthodox. Milica suggests that 'faith' now manifests itself ubiquitously in everyday life, present 'at every step' (see also Radulović 2012: 1).

Noticing her point about people feeling the need to 'demonstrate' their faith, I asked Milica why, in her view, this was so.

I think that to some extent it's some sort of fashion (pomodarstvo). From people that you really wouldn't expect, who you think just don't have the spiritual capacity (duhovni kapacitet). You have to have some virtue. Or strive at least. [But one sees religious activity] from some people with whom you don't see any of that. Again - this is my personal judgement, maybe I'm wrong. You see that they insist on it, that they're believers (vernici), that they're Orthodox, on the Ten Commandments. It's as if they live according to religion (religija), according to faith (vera). I think that in a great number of cases it's some sort of fashion - as if they are following it, like a sort of trendy feature (trendovska odlika).

Again, what we get in Milica's response is her perception of a discrepancy between her understanding of 'spiritual capacity' (which she assumes is essential for engaging seriously with liturgical Orthodoxy) and her view of the sort of people she sees going to church (who she assumes lack that 'capacity'). The way in which some people assert their religious identity stands out for her; they insist on their religious credentials and yet she remains unconvinced by their motivation.

Like other people with more sceptical attitudes to the institutional Church, Milica uses the word 'pomodarstvo', fashion. She expanded:

Somehow it [Orthodox practice] spread amongst the people, somehow it's a mass phenomenon, it's spoken about a lot. Simply as if there is a great presence of all these [religious] questions, the presence of the Church. Maybe it's brought about by religious

\footnotetext{
${ }^{6}$ See: https://www.pewforum.org/2017/11/08/orthodox-christians-are-highly-religious-in-ethiopia-muchless-so-in-former-soviet-union/ (accessed 19 December 2020).
} 
studies (veronauka $)^{7}$ which has been taught in recent years. I don't know what. Overall, I notice an insistence on it.

As well as noting the rapid expansion of church-centric activity, Milica also suggests, however, that there are quite serious sociological reasons behind the turn to Orthodoxy. She draws my attention to Serbia's current socio-economic situation.

To some extent, I believe that this turning to faith has some comforting role. When there's a time of crisis, when you've got transition, when you've got all the troubles that such a situation brings you, people find some refuge (utocíste) in it [faith].... When everything is good, a person is relieved from these sort of heavy thoughts. ${ }^{8}$ And he just doesn't need that sort of vent, that sort of release. It seems to me that they are trying to find a way out of the situation.

She then considers whether the crises that apparently drive people to church might be better understood at the personal or at the national level.

They literally cling to faith as a last resort (slamka spasa) in a crisis. Whether it be a personal crisis ... or some collective trouble. People turn to it as a last resort, as a refuge, they find a comforting thread in all that. That is really, really pronounced [in Serbia]. Now, I can't work out whether it's more pronounced when it's individual, when the individual is involved in a crisis situation. Or whether it's more pronounced at the level of the nation, the collective.

Milica is intellectually curious, thinking out loud. She suggests that people go to church "because of the burden they feel" and that, in doing so, "they become part of some trend". Then she problematises her initial thinking about cause and effect:

Is it a trend and we move with the trend? Or did people start going because of some despair which then became a trend - I don't know. Overall, I notice an expansion.

Writing in 2016, Maja Petrović-Šteger noted that Serbia "seems to have returned to a state of dissatisfaction and uncertainty - the economy is faltering, living standards are poor and levels of public health are worryingly low" (2016: 114). Milica responds to such societal conditions, and situates her analysis of religion firmly within a "time of crisis", as she puts

\footnotetext{
7 Since 2001, religious education (veronauka) has been taught at schools, exposing young people to Orthodox Christian thought in a way that their Yugoslav generation parents were not.

${ }^{8}$ What Milica says here strongly recalls the frequently cited Serbian saying "Bez nevolja, nema bogomolja" - "Without trouble, there is no worship". Curiously she does not mention it (as many of my other interlocutors did), but the tenor of her remarks is very much in the same vein.
} 
it. She seems to genuinely sympathise with the fact that people may face severe hardship, and that this may push them to seek answers in Orthodoxy.

This being said, in economic terms, Milica has a good quality of life, stable employment, and she owns a house with her husband. Her parents also live comfortably in a large house with a big garden. What is striking about Milica's account is her apparent detachment from the phenomenon she describes. She positions herself as an onlooker, a commentator, not directly affected by the crisis she is evoking.

\section{Milica's Orthodoxy}

At this juncture, I asked Milica in more detail about her own, personal relationship to Orthodox spirituality, and why she did not feel moved to engage in liturgical practices herself.

I suppose that a person has to have some capacity. I really believe a person must have some capacity for this sort of spirituality and religiosity. You have to carry that in you. Whether it will awaken in you or not - that's the question. For some people it will, for others it won't. But somehow it seems to me that I really haven't got it, that I can't get over that rational level to go into it so much.

Milica returns to her idea of people either having a 'capacity' for spirituality or not. It is unclear who she thinks actually possesses such a capacity. She personally feels unable to get beyond a 'rational' level. And, as we saw above, she is somewhat sceptical that many regular churchgoers actually have this capacity either.

Milica elaborated on her own relationship to Orthodoxy by telling me about her family upbringing, which she felt had profoundly shaped her understanding of 'religion'.

My family baptised me, my brother too. ... I got married in church. My family celebrates their patron saint day (slava), we celebrate Christmas, and we observe all the feasts in that traditional way - everything as it should be. However, in our family we don't connect so much with that religious base (religiozna baza). That religious base isn't as essential as some traditional models. It means that for us the feast day is important because it's a family gathering. Because with that we root ourselves nationally or in terms of family - here we are on our territory (područje). Roots are important for us. We can't give them up.

What Milica describes here would be familiar to many people across Serbia - Orthodox feasts as family gatherings with only a nominal religious element. Orthodox tradition can be made to connote the membership of the Serbian people and a particular family, with formal liturgical elements being marginalised or overlooked altogether. The slava is 
particularly relevant in this regard. In contemporary Serbia, the celebration of the family patron saint's day is increasingly 'secularised' and affirmative of both Serbian and Orthodox identities - regardless of whether one is 'religious' or not (Bakić-Hayden 2019: 296). Milica clarified further:

That religious feeling doesn't prevail [in my family]. But rather the traditional feeling ..., so that was passed on to my brother and me. We go to church and light candles. [And we go into churches] when we travel.

Again, such an interaction with churches - calling in occasionally to light a candle when one is travelling or feels so inclined - is widely reported in Serbia from people with differing degrees of attachment to the Church. Since most churches are open every day from dawn until dusk, physically entering a church to light candles or venerate the icons does not have to have to coincide with a formal service.

Indeed, at this point, Milica makes a revelation. She tells me that the first time she had actually been to a church service in her life was six months prior to our interview. She had been conducting some archival research for her school at a nearby monastery. Aware of the ongoing services in the monastery church, she decided to attend the Divine Liturgy, along with her female colleague. She explained her motivations:

First of all, I went for a cultural reason - I wanted to see what it looks like. It sounds coarse - but I really didn't go to pray to God. I went to see what a service looks like in our Church, who gathers there, what they speak about. We were present, but we were not part of the prayers. And nor did I have that feeling in me. ... I didn't feel like I belong. I didn't feel like I could participate in that wholeheartedly; I was watching. And that's it - for me it was meaningful because I saw what it looked like.

Milica is very clear that her motivations were secular, cultural ones. Two points stand out. Note that she was curious about what services look like in 'our' Church, that is the Serbian Church. She implicitly positions herself as part of a wider ethnic collectivity that has its own Church, over which she feels a sort of shared ownership. The Church is related to her to a certain degree; it is not completely other. But then she observes that she did not 'feel' part of the service. The Church, or at least the idea of it, she can lay claim to, not so the liturgical practices enacted within.

At one level, Milica seemed quite aware that such a revelation would surprise me, and that there was a dissonance between her quite extended discussion of Orthodoxy and the fact that the first (and at that moment only) time she had attended a Liturgy was in her early thirties. But then she conditioned her point slightly, noting that both her older brother (whom she described as being 'more into' Serbian traditional customs) and her husband (whom she described as coming from an ardently 'Orthodox' family) had also never attended a Liturgy. 
Given that it had been Milica's first experience of Orthodox worship, I asked about her impressions.

I was surprised how much people were into it. How much they participate with their whole being. ... How much they are focused, how much they care, how much they know the whole concept, how much they know that ritual. Well it's not a 'ritual', [she searches for the right word] 'prayers', 'worship' (bogosluženje) in fact. I was surprised at how many generational differences there were: there were children - parents even bring babies. There were young people ... who know the whole service by heart, they sing. It means they go there a lot, obviously, if they know it that well. There are elderly people. I noticed people who were poor - that was clear [from their appearance]. Different economic bands and different generations. That was really interesting for me. And especially that the service was really well attended.

Milica's perception of the demographic diversity of the congregation is consistent with my own observations around Serbia. My more practising interlocutors were demographically diverse, ranging from educators, medical workers and university graduates, to pensioners, unemployed men and housewives. Indeed, the identity of a 'typical believer' - once predominantly rural, elderly and female - has massively diversified (Blagojević 2008; 2012; Malešević 2006: 101). Just as Milica is struck by the diversity of the people gathered in the church, so too she reports being amazed by the extent to which people were committed to Orthodox worship. Such forms of embodied piety (genuflections, bowing, crossing) stood out to her and were worthy of comment.

At this point, Milica started to compare herself to those she sees attending church regularly.

I think that my spiritual being doesn't have the capacity to develop like that. Maybe I could have it, if I were to work on it, if something were to awaken, that impulse. But for now I haven't got it. I simply can't listen to all that [Orthodox dogma], and take it for granted. Because I always ask questions about it. ... If I believed, I wouldn't ask questions.

Milica characterises herself as someone who struggles to accept the more irrational, transcendental aspects of religious belief. Having said that, she reminds me that she was born into an 'Orthodox family' and thus is 'Orthodox' and has 'no dilemmas' in that sense. However:

That dilemma about the existence of God - do I believe in God? - that's what I'm looking for somehow, I'm reconsidering it. My colleague [with whom she attended the Liturgy] said the same. That she can't overcome that irrational level. How will you accept all that? Or the Bible, for example. I see it like a literary work - like a metaphor. 
I don't experience it as Holy Scripture that I take as a whole and live by. ... There are people who are really religious and who experience it literally as Holy Scripture.

Milica imagines that some people take the Holy Scripture 'literally' and she seeks to distance herself from such an understanding. Then she returns to the issue of belief in God, and her ambivalence about that question.

I can't say that I don't believe in God. I believe in the balance of nature, and I believe in virtue (vrlina). So, some beauty, some harmony which exists - in that, definitely. But that belief in God, and that god-fearing (bogobojažljivost) ... [trails off]

Orthodoxy she can accept, but belief in God remains problematic for her.

My overall point here is that what Milica is faces is not a religious 'market place' or a variety of exciting, charismatic alternatives to Orthodox Christianity (cf. Pelkmans 2009; Slagle 2011). Rather, she finds herself in a position of weighing up the beliefs and embodied expressions of a faith tradition which she feels unambiguously is her own, by birthright. Her process of assessing emergent forms of piety became especially clear when we spoke about fasting.

\section{Fasting and sincerity}

In short, the Orthodox liturgical calendar is composed of four main fasting periods, the most arduous being the Lenten fast leading up to Easter. Wednesdays and Fridays are always fasting days, as are other important holidays throughout the year. As we have established, Milica is genuinely surprised by people engaging seriously with liturgical acts. She elaborates, saying:

It's unbelievable to me that so many people keep a forty day fast [before Easter]. ${ }^{9}$ That they're so involved in that question of faith. That they practise so much. It's simply unbelievable for me. It's inconceivable for me! They really have that deep in themselves - that's fascinating for me, really.

I asked Milica whether she had ever fasted herself. She replied that she and her husband fast less frequently than they did before. This is not, she clarified, because she 'ignores' fasts. Rather, it is:

Because the way in which I fast doesn't please me. If I could fast, and if at no moment I had dilemmas about it - [mimics herself] 'oh how I would love to eat that chocolate!'

\footnotetext{
9 Technically speaking, the Lenten fast actually lasts forty-eight days, not forty. Like many people who choose not to seriously engage with and study Orthodox practice, Milica is unsurprisingly unaware of this detail.
} 
- I would fast wholeheartedly. Because I don't feel it in that way, I understand fasting as if I need to deny myself something to show that I can overcome that limit. I clearly don't experience that seriously enough, and I am clearly not in it with my whole heart. Then I say to myself: 'ok, if I can't do it in the right way, I won't do it at all.' It means nothing to me if I fast today and don't feel anything connected to it.

Rather like with her thoughts on people's 'spiritual capacity', here Milica seems to set a bar for her own piety that is higher than she can actually reach. Because she feels that she cannot meet such standards, she withdraws from the practice almost entirely. Note that Milica does not criticize fasting, per se. On the contrary, she clearly takes it very seriously, hence the reason she is bothered about not being able to do it right. The importance she ascribes to fasting becomes especially pronounced when she talks about how other people fast.

It's really widespread amongst the people here. [Imitating people] 'Today is a fast!' 'Day of the Cross (Krstovdan)!' And everybody fasts. Then a bunch of young people wait twelve hours to eat chocolate - and that doesn't have any meaning at all. So it's a fast without any content. Or I don't understand fasting - it should be that I experience it as a sort of feat, it should be a feat, in fact. Or at least restraint. But we have an overflowing table. We have everything. You've got five dishes. You're fasting and you can choose what you're going to eat!

Here, Milica critically intervenes on people not fasting (in her view) sincerely and in the right way. Fasting, she feels, must be about restraint and simplicity, not choice and abundance.

One issue that particularly irritated her (her voice became slightly more excited) was the issue of fasting on a patron saint's day (slava). A 'fasting slava' (posna slava) occurs when the slava falls on a Wednesday or Friday, or else during one of the Church's four yearly fasts. This means that, theoretically, hosts should refrain from serving meat (typically pork) and instead serve fish (see also Bakić-Hayden 2019: 292-293). Being restrained in terms of the ingredients does not necessarily mean that people scrimp on what they lay on for their guests, eager as they are to be good hosts. Indeed, the religious dimension aside, the slava can become an arena in which to show off family status (ibid.: 293). Milica (quite acerbically) raised a point that I heard articulated frequently by people with both stronger and weaker attachments to the Church.

People prepare a fasting slava - and the spread is so rich that I don't see what the fast is. What are we giving up? It's complete nonsense!

She expanded:

If we have accepted the slava, and if we're keeping to that Orthodox codex, and if it's Wednesday and Friday which are fasting days, and if the slava falls on Wednesday or 
Friday - we should fast. It should be fasting food. ... Serbs, increasingly, at least here in my circles ... really try to prepare food that suits them [i.e. trying to avoid the fast]. And now I fight a battle around that - 'why do you do that?!' ... Is the point that we all get together and eat roast pork? Or to recognise that [Orthodoxy] which we've accepted?

There is real frustration here. Milica effectively accuses her compatriots of missing the point of the slava. It should be, she says, about accepting the tenets of Orthodoxy (and its fasting constraints), not about having fun. It clearly matters to her, and she is not left indifferent to people liberally interpreting the rules. What is interesting is that Milica, by her own admission, is highly ambivalent about her own belief in God, amazed at people fasting for extended periods, and a little detached from Orthodox practice. Why, one might legitimately ask, does she get so annoyed about people not observing the fast? I suggest that it is because, in Milica's view, the moral community is coterminous with the ethnic group. For her, fasting cannot be reduced to 'religion'. It is also a Serbian tradition, indexing membership of the wider Serbian moral community with its particular traditional customs. In this sense, Milica necessarily feels connected to such practices. In the final part of the interview, we discussed in more detail the crossover and tensions between ethnic and confessional belonging.

\section{Between religion and nation}

The anthropologist Aleksandra Pavićević has noted that in contemporary Serbian Orthodoxy the emphasis has frequently been on the 'historical' rather than the 'eschatological' aspects of 'religious belonging' (2014: 250). Such a view is clearly illustrated throughout Milica's account. Milica put it like this: "I am more nationally defined, and a lot less religiously." Again, she draws a careful and explicit distinction between being Orthodox in a cultural sense, and a belief in God.

I don't have a dilemma about my Orthodoxy - I'm Orthodox, by tradition. My family is an Orthodox family, and I like that - it brings us together. In that family sense - and in terms of national roots - it's meaningful for me. ... But I have a dilemma when it comes to belief in God, independent of Orthodoxy.

It is well established in the ethnographic literature that not believing in God and asserting an Orthodox Christian identity are mutually compatible positions, both in Serbia (BakićHayden 2019: 296), but also in other traditionally Orthodox countries (see Ghodsee 2009; Ładykowska 2016).

Since she referred to her own baptism several times, I asked Milica whether she would baptise her children. 
Yes! [emphatic]. Yes. I don't have that dilemma. Well I got married in the Church. And that was very meaningful.

There is really no question for Milica - of course, she would baptise them. She reminds me that she had a church wedding ceremony (as well as the obligatory civic one), thus signalling her attachment to and appreciation of such rituals. Milica also adds that this desire to baptise her children stems from a strong personal attachment to Žiča, a medieval monastery just outside Kraljevo.

I love Žiča monastery. In a cultural and historical sense. It is meaningful for our people. I definitely feel that sort of belonging. In that sense, it was meaningful for me. I wanted to get married in the Church. I didn't have a dilemma with that, and nor did my husband.

A priest or theologian, or indeed a more regular churchgoer, might take issue with Milica's view of things. Amongst more practising Orthodox, I heard criticisms of people who viewed monasteries primarily as 'cultural heritage', without appreciating their spiritual value. But Milica is very confident about what an Orthodox identity means for her.

I can feel the presence of Orthodoxy in a traditional sense. With it I somehow confirm my belonging to this territory and people (narod). I am a part of this community ... For me, it goes beyond that religious framework (verski okvir), it really goes beyond that religious framework. It's a cultural, historical and traditional framework for me. Even though it's my way of showing belonging, for me it's super.

The national 'framework', in her view, subsumes the religious 'framework'.

Let's say that that national corpus - cultural, historical corpus - includes Orthodoxy. So it's a part of cultural identity, or national identity. Those are concepts that, for me, go beyond the religious question. ... In that sense, all of that is important. Orthodoxy, the Church and everything are all important to me, because it's part of national and cultural identity, and God is on the side.

This is not a blunt repudiation of Orthodox faith. (In her words: "What Orthodoxy represents is truly beautiful. Virtue, love, brotherly love.") However, what Orthodoxy offers, in Milica's understanding, is a broad moral framework within which she can assert more proximate kinship bonds to her close family, as well as her more extended kinship bonds to the Serbian people.

The 'religious base' that Milica describes is thus potentially distinct from her nationallyrooted sense of Orthodoxy. What is potentially surprising for Western readers is that Milica's understanding of 'religion' is only one aspect of the network of social relationships, practices, and institutions which constitute what Simion Pop calls "Orthodox complex space" 
(2011: 98). Religion is indeed effectively 'objectified' (Asad 1993); it becomes an element which can be incorporated into daily life - or actually left out, avoided. To interpret the situation in Milica's terms: it is not that 'religion' incorporates Orthodoxy, but rather that Orthodoxy incorporates 'religion'.

\section{Conclusion}

What are the broader implications of Milica's account? As I noted at the outset, I have not claimed that she represents a particular segment of the population. Her reflections are obviously patterned with idiosyncrasies and highly subjective viewpoints. What I want to highlight is not so much the specific detail of her opinions, but rather her self-reflexive positionality, per se. It is that which potentially has wider relevance. Milica's positionality is characterised by an ongoing tension between detachment and relatedness. On the one hand, she comments on - and critically evaluates - the embodied Orthodox practices she sees around her. She tries to make sense of them, and measures other peoples' religious activities by her own understandings. At the same time, what Milica sees in contemporary Serbia irritates, fascinates and provokes her - precisely because she feels connected to it. She feels part of a moral whole (we, Serbs), a moral whole of which 'religion' is only one part.

As social scientists examining social change, we need to take seriously the lay sociological accounts of our interlocutors. How do they attempt to objectively interpret and narrate transition and transformation? Moreover, we should interrogate the intellectual genealogy of such local social commentary. Which interpretative devices do people employ to critique Orthodoxy and self-reflexively position themselves against it? Three decades after the collapse of socialist regimes we have to consider, not only how people embrace new religious identities, but also how they made and make sense of such societal changes in their own terms.

\section{Acknowledgements}

Marko Barišić, Timothy Carroll and Rastko Jović offered very insightful and constructive feedback on earlier versions of this text. I am also grateful to the editors of this special issue for their very helpful suggestions. All shortcomings are my own.

\section{Bibliography}

Asad, Talal. Genealogies of religion: Discipline and reasons of power in Christianity and Islam. Baltimore \& London: The Johns Hopkins University Press, 1993.

Bakić-Hayden, Milica. The cross at the crossroads: the feast of slava between faith and custom. In Everyday life in the Balkans, edited by David W. Montgomery, 289-298. Indiana: Indiana University Press, 2019. 
Bielo, James S. (ed.). The Social life of scriptures: cross-cultural perspectives on Biblicism. New Brunswick: Rutgers University Press, 2009a.

Words upon the Word: An ethnography of Evangelical group Bible study. New York: New York University Press, 2009b.

Blagojević, Mirko. "Desecularization of contemporary Serbian society.” Religion in Eastern Europe 28: 1 (2008): 37-50.

"Religijsko-konfesionalna identifikacija i vera u Boga građana Srbije" [Religious and confessional identification and faith in God among the citizens of Serbia]. Filozofija i Društvo 28: 1 (2012): 40-52.

Ghodsee, Kristen. "Symphonic secularism: Eastern Orthodoxy, ethnic identity and religious freedoms in contemporary Bulgaria." Anthropology of East Europe Review 27: 2 (2009): 227-252.

Lackenby, Nicholas. "For many are called, and few are chosen": Peoplehood and eternity amongst Orthodox Christians in Serbia. PhD diss., University of Cambridge, 2020.

Ładykowska, Agata. Orthodox atheists: religion, morality, and education in postsocialist Russia. PhD diss., Martin-Luther-Universität Halle-Wittenberg, 2016.

Malešević, M. Pravoslavlje kao srž 'nacionalonog bića' postkomunističke Srbije [Orthodoxy as the essence of the 'national self' of postcommunist Serbia]. In Svakodnevna kultura u postsocijalističkom periodu u Srbiji i Bugarskoj, edited by Zorica Divac, 99-121. Belgrade: SANU, 2006.

Malley, Brian. How the Bible works: An anthropological Study of Evangelical Biblicism. Walnut Creek: AltaMira Press, 2004.

Pavićević, Aleksandra. Religijska uverenja i praksa stanovništva srednjeg i donjeg Polimlja: narodna religioznost, pravoslavlje i sekularizacioni procesi. [Religious beliefs and praxes in Middle and Lower Polimlje: popular religiosity, Orthodoxy and secularization processes]. Mileševski Zapisi 10 (2014), 249-257.

Pelkmans, Mathijs. Introduction: post-Soviet space and the unexpected turns of religious life. In Conversion after socialism: disruptions, modernisms and technologies of faith in the former Soviet Union, edited by Mathijs Pelkmans, 1-16. New York \& Oxford: Berghahn Books, 2009.

Petrović-Šteger, Maja. Understanding self-care: passing and healing in contemporary Serbia. In Materialities of passing: explorations in transformation, transition and transience, edited by Peter Bjerregaard, Anders Emil Rasmussen \& Tim Flohr Sørensen, 113-129. London \& New York: Routledge, 2016.

Perica, Vjekoslav. Balkan idols: religion and nationalism in Yugoslav states. New York: Oxford University Press, 2002.

Pop, Simion. "Eastern Orthodox Christianity as anthropological object: conceptual and methodological considerations." Studia Ubb Sociologia 56 (2011): 93-108.

Orthodox revivals: prayer, charisma, and liturgical religion. In Praying with the senses: contemporary Orthodox Christian spirituality in practice, edited by Sonja Luehrmann, 216-241. Bloomington: Indiana University Press, 2018.

Radić, Radmila. The Church and the 'Serbian question'. In The road to war in Serbia: trauma and catharsis, edited by Nebojša Popov, 247-273. Budapest \& New York: CEU Press, 2000.

Radić, T. Pregled istraživanja "Religioznost u Srbiji 2010" [Overview of the "Religiosity in Serbia 2010" research]. In Religioznost u Srbiji 2010, edited by Andrijana Mladenović, 13-33. Belgrade: Hrišćanski Kulturni Centar; Centre for European Studies; Konrad Adenauer Stiftung, 2011. 
Radulović, Lidija. Religijja ovde i sada: revitalizacija religije u Srbiji [Religion here and now: the revitalization of religion in Serbia]. Belgrade: Srpski Genealoški Centar, 2012.

Slagle, Amy. The Eastern Church in the spiritual marketplace: American conversions to Orthodox Christianity. DeKalb: NIU Press, 2011.

Zigon, Jarrett. Aleksandra Vladimirovna: moral narratives of a Russian Orthodox woman. In Religion, morality, and community in post-Soviet societies, edited by Mark D. Steinberg \& Catherine Wanner, 85-113. Bloomington \& Indianapolis: Indiana University Press, 2008. 